\title{
УДК: 159.9
}

\section{https://doi.org/10.52058/2786-4952-2021-3(3)-279-290}

Хохліна Олена Петрівна доктор психологічних наук, професор, професор кафедри авіаційної психології, Національний авіаційний університет, просп. Любомира Гузара, 1, м. Київ, 03058, тел.: (066) 750-26-62, e-mail: epkhokh@ukr.net, https://orcid.org/0000-0002-2126-5011

Середіна Олександра Дмитрівна студентка магістратури, Національний авіаційний університет, просп. Любомира Гузара, 1, м. Київ, 03058, тел.: 0631961504, e-mail: oleksandraseredina@gmail.com, https://orcid.org/0000-0002$8739-4940$

\section{ОСОБИСТІСНИЙ ПРОФІЛЬ СТУДЕНТІВ 3 ЕФЕКТИВНОЮ УЧБОВОЮ ДІЯЛЬНІСТЮ}

Анотація. У статті представлено результати теоретико-емпіричного дослідження, присвяченого визначенню особистісного профілю успішних студентів на основі виявлення наявності та характеру зв'язку ефективності учбової діяльності (учіння) з типологічними особливостями їхньої особистості.

У дослідженні учіння трактується як свідома i мотивована діяльність суб'єкта, що спрямовується на опанування ним знаннями, вміннями й навичками та на його особистісне становлення. Однією з головних його характеристик, як і діяльності в цілому, є ефективність, яка у студентів визначається, перш за все, академічною успішністю. Психологічними детермінантами, які можуть забезпечувати ефективність учбової діяльності студентів, розглядаються особистісні властивості, до яких, відповідно до структури особистості О.Г.Ковальова, належать самосвідомість, спрямованість, здібності, характер і темперамент.

Емпірично виявлено, що серед респондентів переважає кількість студентів, які мають високий рівень академічної успішності. Отримані дані щодо прояву у них особистісних властивостей, а саме самосвідомості, показало, що більшості притаманна адекватна самооцінка та високий рівень домагань; смисложиттєві орієнтації, як складова спрямованості особистості, у них мають середній рівень сформованості 3 домінуванням орієнтацій на теперішне (процес життя) та уявлення про себе як «господаря свого життя». Відповідно до результатів вивчення здібностей, характеру та темпераменту, виявлено, що у студентів переважають середній та високий рівень загальних (інтелектуальних) здібностей; виразними $\epsilon$ емотивний та екзальтований типи акцентуацій характеру; у більшості наявний холеричний та флегматичний типи темпераменту.

Кореляційний аналіз отриманих даних, з метою з'ясування наявності зв'язку між ефективністю учіння студентів та їхніми особистісними властивостями, 
показав наявність зв'язку із самосвідомістю (рівень домагань), спрямованістю (смисложиттєві орієнтації) та здібностями (загальні інтелектуальні); акцентуації характеру й темпераментальні особливості особистості на ефективності учбової діяльності не позначаються, i навпаки. При цьому статистично значущі відмінності груп досліджуваних 3 різною академічною успішністю виявлено щодо рівня домагань та інтегрального показника загальних (інтелектуальних) здібностей. Отримані результати були покладені в основу побудови особистісного профілю студента з ефективною учбовою діяльністю.

Ключові слова: особистість, особистісні властивості, діяльність, учбова діяльність, ефективність діяльності, студенти.

Khokhlina Olena Petrivna Doctor of Psychological Sciences, Professor, Professor of Aviation Psychology Department of the National Aviation University, Liubomyra Huzara Ave., 1, Kyiv, 03058, tel.: (066) 750-26-62, 0677248608, e-mail: epkhokh@ukr.net, https//orcid.org/0000-0002-2126-5011

Seredina Oleksandra Dmytrivna Master of Psychology of the National Aviation University, Liubomyra Huzara Ave., 1, Kyiv, 03058, tel.: (063) 196-15-04, email: oleksandraseredina@gmail.com, https://orcid.org/0000-0002-8739-4940

\section{PERSONAL PROFILE OF STUDENTS WITH EFFECTIVE LEARNING ACTIVITY}

Abstract. The article presents the results of theoretical and empirical research devoted to determining the personal profile of successful students on the basis of identifying the presence and nature of the correlation of effectiveness of learning activity (learning) with the typological features of their personality.

The research interprets learning as a conscious and motivated activity of the subject, which is aimed at mastering they knowledge, skills and abilities and at they personal formation. One of its main characteristics, as well as activity as a whole, is efficiency, which in students is determined, first of all, by academic performance. Psychological determinants which can provide efficiency of students' learning activity are considered to be personal properties which, according to A.G. Kovalev's personality structure, include self-consciousness, personality trend, abilities, character and temperament.

It was found empirically that the number of students with high level of academic performance prevails among the respondents. The obtained data on the manifestation of personal properties, namely self-consciousness, showed that most of them have adequate self-esteem and a high level of aspiration; meaning-life orientations, as a component of personality trend, they have an average level of formation with the dominance of orientation to the present (process of life) and the idea of themselves as the "master of their life". According to the results of the study of abilities, character and temperament, it was found that students have medium and high level of general 
(intellectual) abilities; expressive are emotive and exalted types of character accentuation; most have choleric and phlegmatic types of temperament.

Correlation analysis of the obtained data, in order to find out the connection between students' learning efficiency and their personal characteristics, showed a connection with self-consciousness (level of pretension), orientations (sense-life orientations) and abilities (general intellectual); character accentuation and temperamental features of personality do not affect the efficiency of learning activity, and vice versa. At the same time, statistically significant differences between the groups of examinees with different academic performance were found on the level of pretensions and the integral index of general (intellectual) abilities. The results were used as a basis for constructing a personal profile of a student with effective learning activity.

Keywords: personality, personal qualities, activity, learning activity, effectiveness of activity, students.

Постановка проблеми. На сьогодні в Україні відбуваються інтенсивні соціально-економічні зміни. На ринку праці майже не щодня потребуються нові висококваліфіковані робітники та спеціалісти, тому постійно зростає і рівень конкуренції. Завдяки цьому зростають і вимоги до кандидатів, здатних до ефективної професійної діяльності. Це, своєю чергою, вимагає від фахівця підготовленості - наявності необхідних знань та способів дій (навичок та вмінь), a також сформованості важливих для успішного виконання діяльності особистісних утворень, як і особливостей психічного розвитку загалом.

Підготовка майбутніх фахівців здійснюється щонайперше в період навчання у вищому навчальному закладі, під час якого відбувається інтенсивне становлення та розвиток дорослої особистості. У зв'язку з цим залишається актуальною проблема становлення особистості студента як суб'єкта діяльності, постає завдання проведення досліджень у напрямі виявлення психологічних, зокрема особистісних, детермінант ефективного здійснення учбової діяльності студентів. Використання ж результатів таких досліджень на практиці сприятиме підвищенню рівня підготовки майбутніх фахівців до професійної діяльності, їхньої конкурентоспроможності, збільшенню кількості розумних, мотивованих та самодостатніх випускників.

Аналіз останніх досліджень i публікацій. В основу визначення теоретичних засад дослідження покладено аналіз наукових джерел з проблеми діяльності загалом та учбової діяльності зокрема таких вчених, як: Л.С. Виготський, П.Я. Гальперін, В.В. Давидов, Д.Б. Ельконін, .С. Костюк, О.М. Леонтьєв, В.В. Рєпкін, Л.С. Рубінштейн, а також сучасних українських вчених, серед яких: Г.О. Балл, І.Д. Бех, С.Д. Максименко, С.В. Понікаровська, А.М. Сингаївська, М.М. Філоненко, О.П. Хохліна, І.М. Шаповал та ін.

Для розуміння суті особистості та визначення іiі структурних компонентів був проведений аналіз праць таких вчених, як: Б.Г. Ананьєв, І.Д. Бех, Л.С. Виготський, О.Т. Кузнєцова, О.Г. Ковальов, Г.С. Костюк, Б.Ф. Ломов, 
С.Д. Максименко, К.К. Платонов, В.В. Рибалка, Т.М. Титаренко, Н.Р. Тичинська, В.В. Турбан, М.М. Фіцула, О.П. Хохліна та ін. Водночас, як свідчить аналіз наукових джерел, незважаючи на значні здобутки психологічної науки 3 проблеми дослідження, вона потребує подальшого вивчення. Зокрема, постає завдання визначення особистісного профілю успішних студентів з метою пошуку напряму підвищення ефективності навчально-виховного процесу у вищих навчальних закладах, спрямованого на підготовку успішного професіонала.

Метою статті $\epsilon$ висвітлення результатів теоретико-емпіричного дослідження 3 визначення особистісного профілю успішного студента на основі виявлення наявності та характеру зв'язку ефективності учбової діяльності з типологічними особливостями особистості студентів.

Виклад основного матеріалу. На теоретичному етапі дослідження, в результаті вивчення наукових джерел, було з'ясовано суть проблеми, іiї основних питань та ключових понять.

До однієї з базових та фундаментальних категорій у психології відносять поняття діяльності, яке трактується багатьма авторами по-різному. Однак, аналізуючи наукові праці вчених, ми дійшли висновку, що діяльність розглядається виключно як людська форма активності, змістом якої є доцільне перетворення навколишньої дійсності (створення, зміна тощо). У більш вузькому розумінні діяльність $є$ активністю, що регулюється усвідомленою метою (Л.С. Рубінштейн, О.М. Леонтьєв, Б.Ф. Ломов, О.П. Хохліна та ін.). У найбільш абстрактному та загальному визначенні категорія діяльності розкриває відношення «суб’єкт-об’єкт» (Б.Ф. Ломов). При цьому, як підкреслює О.М. Леонтьєв, діяльність - це реальний зв'язок суб'єкта з об'єктом, у який необхідним чином включена психіка [1-3]. Зазначимо, що суб'єктом розглядається носій діяльності, джерело активності, спрямованої на об'єкт.

Якщо суть діяльності розглядати в онтогенетичному плані, необхідно сказати про поняття провідного виду діяльності, яке введене у психологію О.М. Леонтьєвим. Діяльність конкретизується відповідно до певних вікових періодів онтогенетичного розвитку людини у вигляді провідних іiї видів: ігрової, учбової, трудової. Саме гра для дошкільника, учіння для школяра та праця на подальших відрізках життя є тією діяльністю, яка найбільшою мірою визначає психічний розвиток особи. Провідна діяльність - це не лише домінуюча серед інших на певному етапі онтогенезу людини. Найхарактернішим для провідної діяльності $\epsilon$ те, що 3 iï становленням відбуваються найголовніші зміни в психіці людини й формуються психічні процеси, які готують іiї перехід до нової, вищої сходинки розвитку. Кожній провідній діяльності відповідає певний рівень розвитку психіки; кожна 3 них характеризується своїм змістом та структурою: цілями і відповідними їм діями, одиницями аналізу (у грі - роль, в учінні - учбова задача, у праці практична задача). Саме через таку діяльність навколишня дійсність найбільшою мірою впливає на особу, включаючи й доцільний педагогічний вплив з метою її розвитку[1; 4-6 та ін.]. 
Таким чином, провідною діяльністю для студента $\epsilon$ учбова, яка розглядається як свідомий, мотивований процес знаходження, отримання та присвоєння соціального досвіду (у вигляді певних знань, умінь та навичок), який особа перетворює на власний, у ході чого відбувається розвиток особистості (В.М. Синьов, О.П. Хохліна) [6 та ін.].

Будь-яка діяльність характеризується низкою ознак, однією 3 яких є іi продуктивність. Продуктивність діяльності свідчить про отриманий результат, про отримання продукту діяльності чи його зміни, про факт, що після завершення діяльності світ змінився. Продуктивність (результативність), своєю чергою, відноситься до основних параметрів ефективності, успішності діяльності [6]. Якщо ж говорити про ефективність учбової діяльності (учіння) студентів, то вона визначається, щонайперше, академічною успішністю, тобто рівнем учбових досягнень, який оцінюється відповідними балами.

На ефективності учбової діяльності позначається багато зовнішніх на внутрішніх чинників. Серед внутрішніх чинників ефективності учіння студентів особливе місце належить їхнім психічним властивостям, які співвідносяться 3 основними структурними компонентами особистості. Саме особистісне становлення $є$ вершинною метою психічного розвитку людини (О.Г. Асмолов, В.В. Давидов, О.О. Леонтьєв, В.В. Рибалка та ін.). Особистість розглядається як унікальна та неповторна форма буття психіки людини, проявами якої є цільність, усвідомлена предметна діяльність, можливість та прагнення до саморозвитку та самореалізації (С.Д. Максименко). Особистість - це саморегульоване системне утворення, що складається 3 соціально-значущих психічних властивостей, які забезпечують вибірковість відношень та регуляцію поведінки людини як поведінки суб'єкта активності, в тому числі й щодо себе, свого розвитку [1 та ін.].

До основних чинників, що зумовлюють становлення особистості відносяться процес соціалізації (як зовнішня детермінанта) та індивідуалізація (як внутрішня) [1 та ін.]. У ході соціалізації індивід оволодіває суспільно-історичним досвідом, під час якого у нього у нього відбувається формування моральних та духовних цінностей, світогляду, навичок взаємодії з соціумом тощо. Під час індивідуалізації в особи вибудовується внутрішній світ, самостійність, прояви ініціативи по відношенню до власного життя і т.д., що уможливлюється становленням самосвідомості, здатності до саморегуляції та саморозвитку. Так, сукупність зовнішніх та внутрішніх детермінант забезпечує цілісність та завершеність становлення особистості.

Для повноти розуміння суті особистості, розглянемо деякі іiі структури, запропоновані вченими.

Так, у своїй структурі особистості С.Л. Рубінштейн виокремлював три основні підструктури: 1) спрямованість особистості, проявами якої є переважаючі мотиви, інтереси, потреби, ідеалі, світогляд; 2) знання, навички, уміння, здобуті протягом життя у процесі пізнавальної діяльності; 3) індивідуально-типологічні особливості особистості, що проявляються як темперамент, здібності, характер [7].

На сьогодні однією 3 найпоширеніших моделей структури особистості $є$ 
запропонована О.Г. Ковальовим, в якій виділяються п'ять основних компонентів: самосвідомість, спрямованість, здібності, характер, темперамент [1; 8]. Саме ця структура покладалася нами в основу визначення концептуальних засад емпіричного дослідження.

Самосвідомість розуміється вченим як компонент, піднесений над всіма іншими; це система управління, вищий рівень свідомості, що здійснює функцію саморегуляції, і маркується поняттям «Я». Самосвідомість характеризується емоційним відношенням до себе, знанням та уявленням особи про саму себе, тому іiі основу складають самооцінка та рівень домагань.

Спрямованість особистості - система спонук, завдяки яким відбувається вибіркове ставлення до реальної дійсності та діяльності; до неї відносять потреби, мотиви, інтереси, властивості, ідейну та практичні установки.

Здібності розглядаються як сукупність здатностей людини успішно виконувати певну діяльність, які є взаємопов'язаними й постійно взаємодіючими. Прийнято виділяти загальні (інтелектуальні) та спеціальні (до конкретних видів діяльності) здібності.

Складне синтетичне утворення, за допомогою якого відображається індивідуальний стиль діяльності, що демонструє зміст і форму духовного життя людини, називається характером. Як зазначає О.Г. Ковальов, незважаючи на те, що характер - значна частина складної системи властивостей особистості, він не виражає їі в цілому.

Науковець розглядає темперамент як найбільш біологічно обумовлену складову частину структури особистості, основою якої виступають особливості нервової системи, а саме співвідношення характеристик процесів збудження й гальмування, що певним чином впливає на перебіг всіх сторін психічного життя та обумовлює індивідуальний стиль буття кожної особи[1; 8].

На емпіричному етапі дослідження 1) виявлявся рівень академічної успішності та особистісні властивості студентів; 2) з'ясовувалися наявність та характер зв'язку між академічною успішністю студентів та проявами у них особистісних властивостей; 3) був побудований особистісний профіль успішного студента.

У дослідженні взяли участь 30 студентів 1-5 курсів Національного авіаційного університету та Національного університету «Києво-Могилянська академія», що навчаються за спеціальностями «Психологія», «Маркетинг», «Прикладна математика», «Соціологія», «Міжнародні відносини», «Економіка», «Фінанси», «Право», «Управління персоналом», «Філологія». Гендерний аспект до уваги не брався.

Вивчення рівня академічної успішності студентів здійснювалося за допомогою анкетування у вигляді Гугл-форм. Для виявлення особистісних властивостей студентів використовувалося тестування за допомогою стандартизованих психологічних методик. Так, для вивчення самооцінки та рівня домагань як компонентів самосвідомості була застосована методика «Діагностики самооцінки особистості» Дембо-Рубінштейн (модифікація А.М. Прихожан); для виявлення смисложиттєвих орієнтацій як складової частини спрямованості особистості - однойменний тест (СЖО, адаптація Д.О. Леонтьєва); 
для виявлення рівня загальних (інтелектуальних) здібностей застосовувалась методика «Короткий орієнтаційний тест «(КОТ, В.Н. Бузіна, Е.Ф. Вандерлік); для визначення акцентуацій характеру використовувалась методика, запропонована К. Леонгардом (модифікація Г. Шмішека); для визначення типів темпераменту застосовувався тест-опитувальник Г. Айзенка «ЕРІ» (адаптація О.Г. Шмельова).

У результаті проведеного емпіричного дослідження було з'ясовано, що серед вибірки переважають студенти з високим рівнем академічної успішності (43\%), дещо менша частка - 3 низьким рівнем (33\%), і найменшу кількість складають студенти з середнім рівнем успішності учбової діяльності (24\%).

Вивчення особистісних властивостей особистості показало наступне.

1. Більшості студентів в характеристиці самосвідомості особистості притаманний високий та середній рівні адекватної самооцінки, а також високий рівень домагань (рис.1, рис.2).

Особи, які мають середні або досить високі показники, характеризуються як люди з адекватним сприйняттям та оцінюванням себе. Високі показники рівня домагань говорять про адекватне, реалістичне усвідомлення особами своїх можливостей, що позитивно позначається на особистісному розвитку.

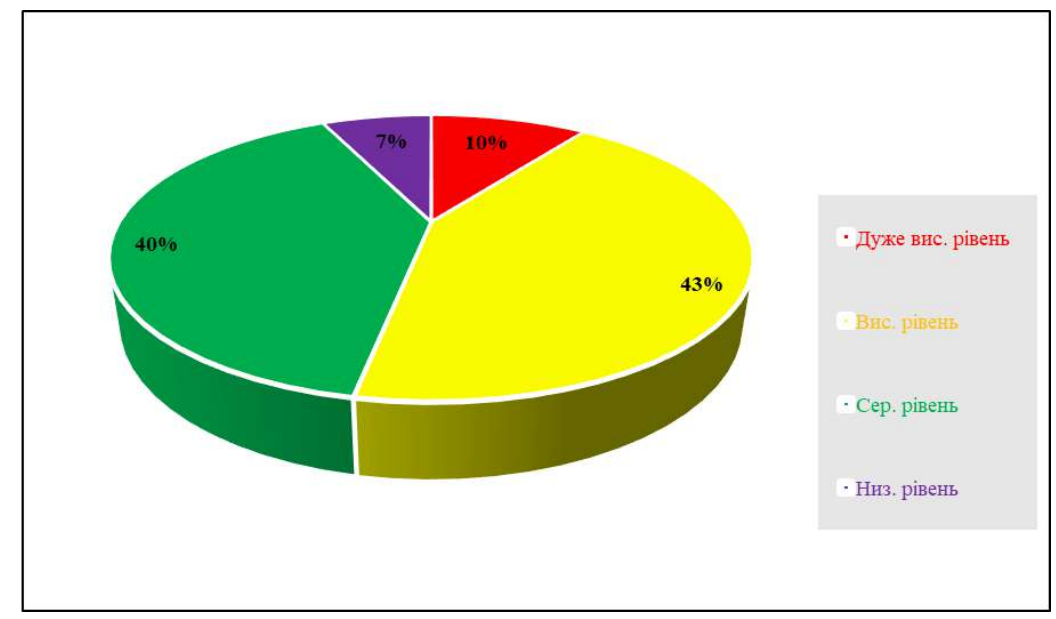

Рис. 1. Процентне співвідночення рівнів самооцінки у студентів

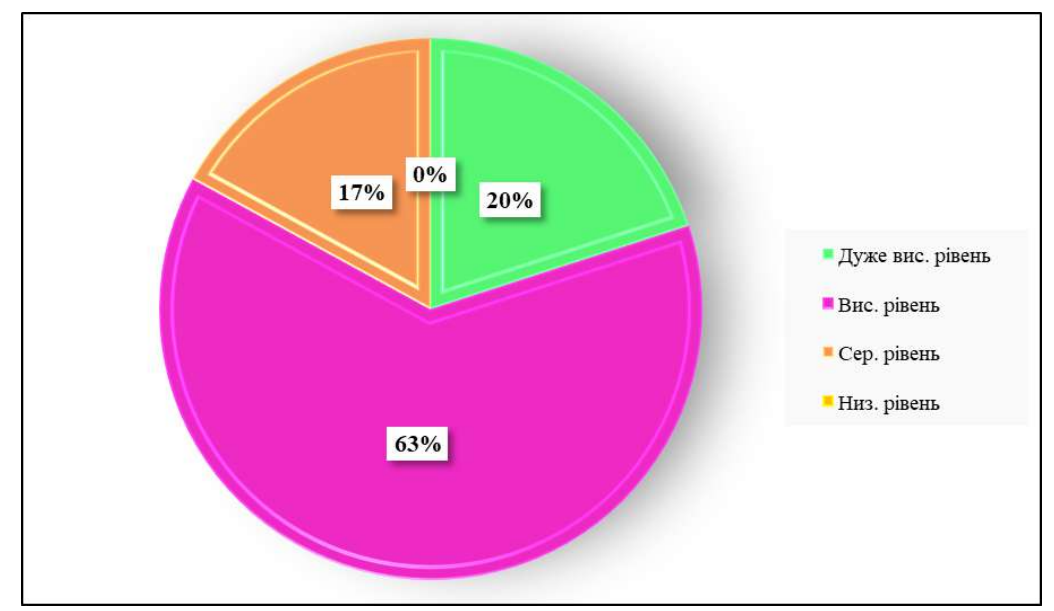

Pис. 2. Дані щзодо відсоткового розподілу рівня домагань у студентів 
2. У спрямованості особистості студентів домінуючими є орієнтації на теперішнє (процес життя) та уявлення про себе «як господаря свого життя» (рис. 3), що свідчить про достатню осмисленість життя, насиченість емоціями та інтересом і впевненість у власних можливостях буття за власним планом.

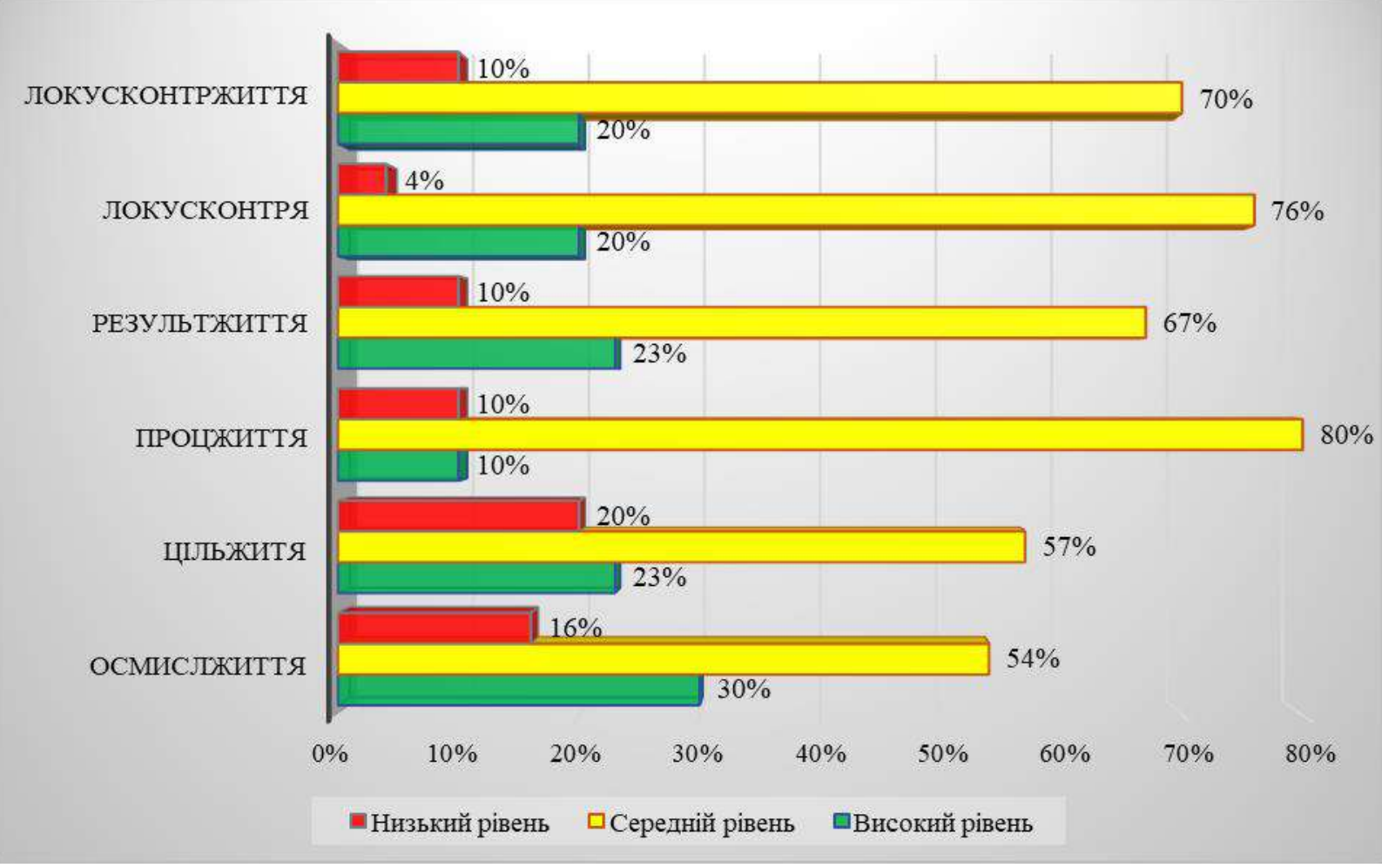

Рис. 3. Відсотковий розподіл рівнів смисложиттєвих орієнтацій студентів

3. Загальні (інтелектуальні) здібності, що забезпечують високий рівень научуваності, розвинені у студентів на високому або вище середнього рівнях (табл.1). Це свідчить про належну сформованість пізнавальних психічних процесів, вершинне місце серед яких займає мислення та наявність сформованих розумових якостей, а саме: узагальненості, усвідомленості, самостійності, гнучкості, стійкості та ін.

Таблиия 1 Дані щодо рівнів інтегрального показника загальних здібностей у студентів

\begin{tabular}{|c|c|c|}
\hline $\begin{array}{c}\text { Рівні загальних } \\
\text { здібностей }\end{array}$ & $\begin{array}{c}\text { Кількість } \\
\text { респондентів }\end{array}$ & \% респондентів \\
\hline Високий & 22 & 73 \\
\hline Середній & 8 & 27 \\
\hline Низький & 0 & 0 \\
\hline
\end{tabular}

4. Серед типів акцентуацій характеру домінуючими у більшості студентів виявилися емотивний та екзальтований типи акцентуацій (рис.4). 
Так, особи з високим рівнем акцентуації емотивного типу характеризуються сильною емоційною чутливістю, високим рівнем емпатії, тривожності, співчутливістю та чуйністю. Студенти з вираженою акцентуацією екзальтованого типу відрізняються здатністю захоплюватися будь-чим, вони насолоджуються кожним моментом життя, балакучі, швидко закохуються, комунікабельні та товариські, але при трагічних або сумних обставинах легко впадають у відчай.

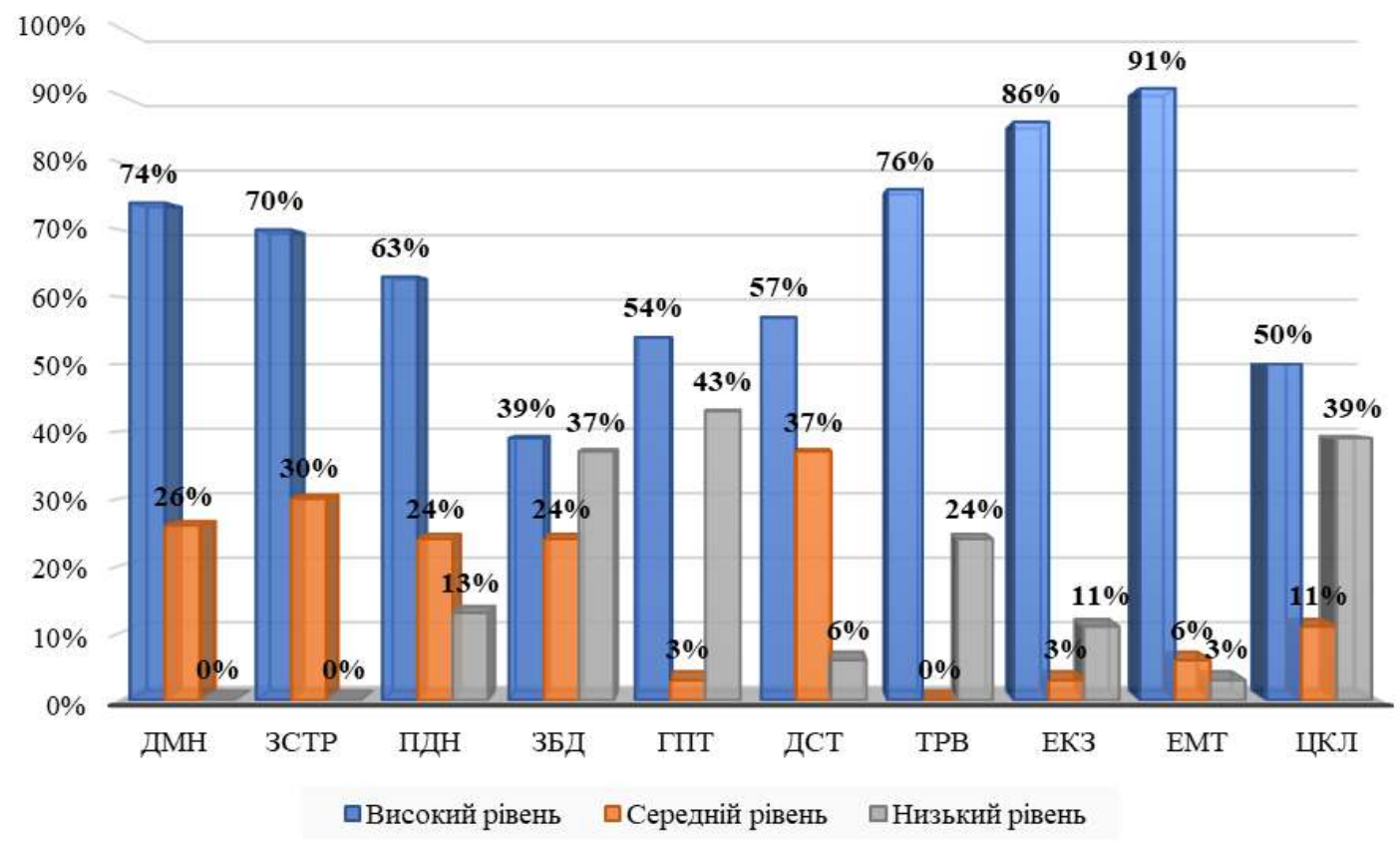

Рис. 4. Відсоткове співвідношення рівнів прояву різних типів акцентуацій характеру у студентів

5. Серед вибірки студентів переважають особи 3 холеричним та флегматичним типами темпераменту (рис.5).

Так, холерикам характерна сильна нервова система, що визначає їхню активність, ініціативність, балакучість, вміння з легкістю переключатися з одного виду діяльності на інший, разом 3 тим через неврівноваженість процесів гальмування і збудження можуть конфліктувати з іншими, оскільки схильні до різкої зміни емоційного фону, імпульсивності, нетерплячості та запальності. Флегматики характеризуються сильною та врівноваженою нервовою системою, що забезпечує високий рівень витривалості, працездатності, толерантності до монотонності, емоційної стійкості, однак через інертність нервової системи можуть мати труднощі при адаптації до нових умов, а також при комунікації 3 іншими, оскільки є досить соціально пасивними. 


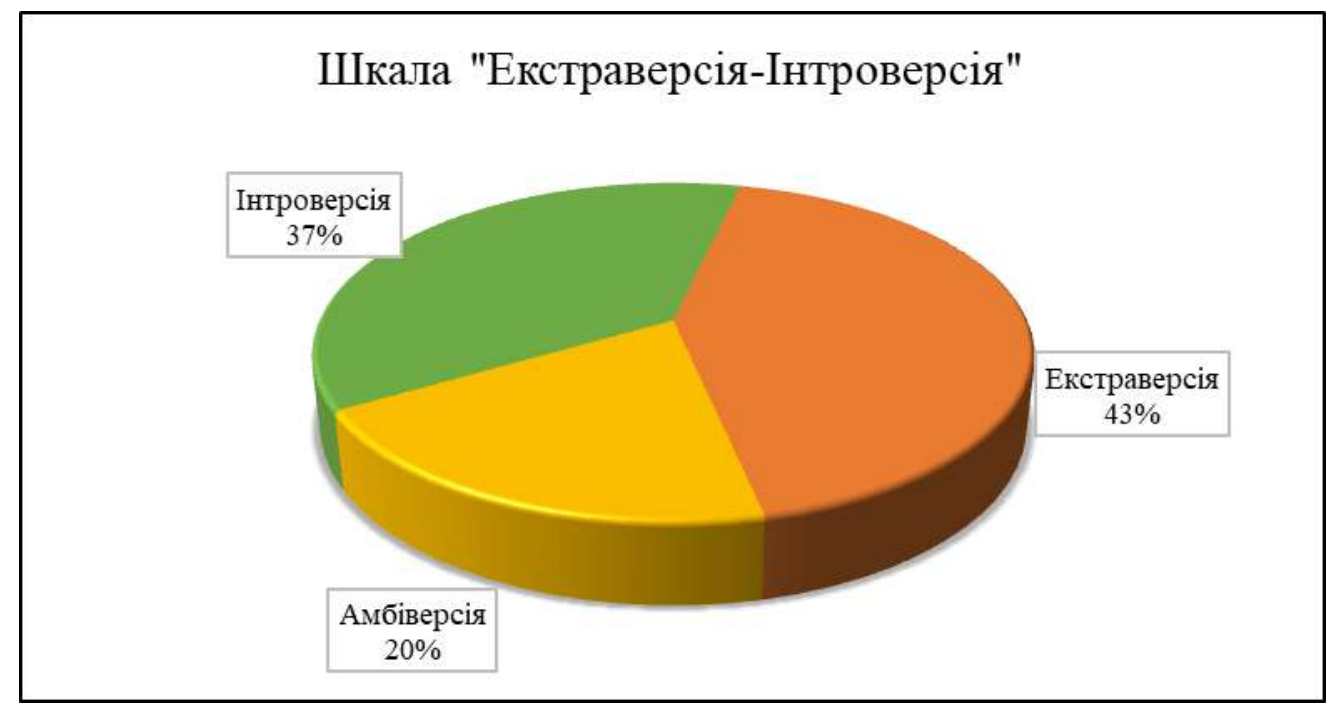

Рис. 5. Відсоткове співвідношення екстравертів, амбівертів та інтровертів серед студентів

Кореляційний аналіз отриманих емпіричних даних дозволив виявити наявність зв'язку ефективності учбової діяльності досліджуваних з певними особистісними властивостями. Так, академічна успішність прямо корелює 3 такими властивостями, як рівнем домагань (самосвідомість), смисложиттєвими орієнтаціями, а саме шкалою «результативність життя» (спрямованість), та загальними (інтелектуальними) здібностями.

У таблиці 2 наведені результати зв'язку ефективності учіння (академічної успішності) з особистісними властивостями студентів.

Таблиия 2

\section{Результати кореляційного аналізу даних академічної успішності та особистісних властивостей студентів}

\begin{tabular}{|c|c|c|c|c|}
\hline \multicolumn{2}{|c|}{ Шкали } & $\begin{array}{c}\text { Результативність } \\
\text { життя }\end{array}$ & $\begin{array}{c}\text { Рівень } \\
\text { домагань }\end{array}$ & $\begin{array}{c}\text { Інтегральний } \\
\text { показник } \\
\text { загальних } \\
\text { здібностей }\end{array}$ \\
\hline \multirow{2}{*}{$\begin{array}{c}\text { Академічна } \\
\text { успішність }\end{array}$} & $\begin{array}{c}\text { Коефіцієнт } \\
\text { кореляції }\end{array}$ &, $440 *$ &, $469 * *$ &, $450 *$ \\
\cline { 2 - 5 } & Значимість & $\mathrm{p} \geq 0,01$ & $\mathrm{p} \geq 0,01$ & $\mathrm{p} \geq 0,01$ \\
\hline
\end{tabular}

Отримані дані, таким чином, свідчать про те, що чим ефективнішою буде діяльність учіння студентів, тим вищий рівень домагань вони матимуть, і навпаки. Те ж відноситься й до сенсу життя, результати якого їх задовольняють. Чим успішнішою буде учбова діяльність студентів, тим життя набуватиме для них більшого сенсу, оскільки він пов'язаний з реалізацією індивідуальності та продуктивністю життя. Кореляційні дані також свідчать про зв'язок ефективності діяльності учіння студента з рівнем інтелекту (інтелектуальними здібностями), 
який забезпечує легкість засвоєння та виконання інтелектуальної діяльності, чим i $є$ учіння. Дослідженням також виявлено відсутність кореляційного зв'язку ефективності учіння студентів 3 акцентуаціями характеру, як і темпераментальними особливостями особистості.

Здобуті результати кореляційного аналізу були доповнені даними про статистично значущі відмінності груп студентів 3 різною академічною успішністю, яка вбачається у таких особистісних компонентах, як самосвідомість - рівень домагань, та інтегральний показник загальних (інтелектуальних) здібностей, що представлено у таблиці 3.

Таблиия 3

\section{Статистично значущі відмінності груп студентів 3 різною} академічною успішністю (за t-критерісм Стьюдента)

\begin{tabular}{|c|c|c|c|}
\hline \multirow{2}{*}{ Назва шкал } & \multicolumn{2}{|c|}{ Середні значення } & \multirow{2}{*}{ t-критерій } \\
\cline { 2 - 3 } & Група 1 & Група 2 & 2,385 \\
\hline Рівень домагань & 84,9 & 77,30 & 2,594 \\
\hline $\begin{array}{c}\text { Інтегральний } \\
\text { показник загальних } \\
\text { здібностей }\end{array}$ & 31,40 & 25,60 & \\
\hline
\end{tabular}

Примітка: група 1 - студенти, що навчаються на «відмінно» та «добре»; група 2 - студенти, що навчаються на «задовільно».

Так, вищий рівень домагань та показник загального рівня інтелектуальних здібностей мають студенти 3 кращою академічною успішністю, ніж студенти 3 низьким рівнем академічної успішності. Таким чином, згідно 3 отриманими даними, нами був побудований особистісний профіль успішного студента відповідно до якого він має бути наділений особистісними властивостями, що складають такі компоненти особистості, як самосвідомість, спрямованість і здібності. А характеризують їх, власне: 1) високий рівень домагань; 2) знайдений сенс життя та задоволеність його результатами; 3) високий рівень інтелектуальних здібностей.

Висновки. Емпіричним шляхом отримано наукові дані щодо наявності зв'язку між ефективністю їхньої учбової діяльності (академічною успішністю) та особистісними властивостями студентів за проявами іiі самосвідомості, спрямованості та здібностей, а саме: рівня домагань, сенсу (результативності) життя та інтегрального показника загальних інтелектуальних здібностей. Акцентуації ж характеру, як і темпераментальні особливості особистості, на ефективності учбової діяльності студентів не позначаються.

Отримані дані щодо кореляції особистісних властивостей з ефективністю діяльності учіння у студентів мають практичне значення, оскільки визначають необхідність формування у студентів самосвідомості, інтелектуальних здібностей та спрямованості особистості задля успішної учбової діяльності, і навпаки: підвищення рівня академічної успішності сприятиме становленню у студентів 
зазначених особистісних утворень, важливих для їхнього професійного зростання.

\section{Jimepamypa:}

1. Хохліна О.П. Теоретико-методологічні проблеми психології: навч. посіб. Київ: Симоненко O.I., 2021. 244 с.

2. Леонтьев А.Н. Деятельность. Сознание. Личность. Москва: Смысл, Академия, 2005. $352 \mathrm{c}$.

3. Хохліна О.П. До проблеми змісту базових категорій психології. Юридична психологія. 2017. №1. C.21-34.

4. Хохліна О.П., Кущенко І.В., Гребенюк М.О. Загальна психологія: Хрестоматія: у 3-х частинах. Частина 3. Київ: Національна академія внутрішніх справ, 2014. 166 с.

5. Леонтьев А.Н. Избранные психологические произведения: В 2-х т. Т.1 Москва: Педагогика. 1983. С.281-293.

6. Синьов В.М., Хохліна О.П. Категорія діяльності: сутність та використання у психолого-педагогічних дослідженнях. Актуальні питання корекційної освіти (педагогічні науки). Зб. наук. пр. Вип. 16. Том 1 / за ред. М.К. Шеремет. Кам'янець-Подільський: Видавець Ковальчук О.В., 2020. С.230-244.

7. Рубинштейн С.Л. Основы общей психологии. Санкт-Петербург: Питер, 2007. 713 с.

8. Ковалев А. Г. Психологическая структура личности. Общая психология / под ред. В.В. Богословского. Москва: Просвещение, 1981. С.70-73.

\section{References:}

1. Khokhlina, O.P. (2021). Teoretyko-metodolohichni problemy psykholohii [Theoretical and Methodological Problems of Psychology]. Kyiv: Symonenko O.I. [in Ukrainian].

2. Leont'ev, A.N. (2005). Dejatel'nost'. Soznanie. Lichnost' [Activity. Consciousness. Personality]. Moskva: Smysl, Akademija [in Russian].

3 Khokhlina, O.P. (2017). Do problemy zmistu bazovykh katehorii psykholohii [To the problem of the content of the basic categories of psychology]. Yurydychna psykholohiia - Legal Psychology, 1, 21-34 [in Ukrainian].

4. Khokhlina, O.P., Kushchenko, I.V., \& Hrebeniuk, M.O. (2014). Zahalna psykholohiia: Khrestomatiia: u 3-kh chastynakh [General Psychology: Textbook: in three parts]. (Vols.3). Kyiv: Nacional'na akademiya vnutrishnix sprav [in Ukrainian].

5. Leont'ev, A.N. (1983). Izbrannye psihologicheskie proizvedenija [Selected Psychological Works]. (Vols. 1) (pp. 281-293). Moskva: Pedahohyka [in Russian].

6. Synov, V.M., \& Khokhlina, O.P. (2020). Katehoriia diialnosti: sutnist ta vykorystannia u psykholoho-pedahohichnykh doslidzhenniakh [The category of activity: the essence and use in psychological and pedagogical research.]. M.K. Sheremet (Eds.), Aktualni pytannia korektsiinoi osvity (pedahohichni nauky) - Actual Questions of Correctional Education (Pedagogical Sciences). Vols. 1 (16), (pp. 230-244). Kam'ianets-Podilskyi: Vydavets Kovalchuk O.V. [in Ukrainian].

7. Rubinshtejn, S.L. (2007). Osnovy obshhej psihologii [Fundamentals of General Psychology]. Sankt-Peterburg: Piter [in Russian].

8. Kovalev, A.G. (1981). Psihologicheskaja struktura lichnosti [The psychological structure of personality.]. V.V. Bogoslovskogo (Eds.), Obshhaja psihologija - General Psychology, (pp. 70-73). Moskva: Prosveshhenie [in Russian]. 